\title{
Silver-Releasing Micro-/Nanoporous Coating on Additively Manufactured Macroporous Ti-Ta-Nb-Zr Scaffolds with High Osseointegration and Antibacterial Properties
}

\author{
Zhenhuan $\mathrm{Wu}^{1}{ }^{1}$, Junsi Luo ${ }^{1}$, Jianying Zhang ${ }^{1}{ }^{\circledR}$, Haokun Huang ${ }^{1}$, Zongyu Xie ${ }^{2}$ and Xiaoli Xie ${ }^{1, *}$ \\ 1 Xiangya Stomatological Hospital, Central South University, Changsha 410078, China; \\ wuzhenhuan@csu.edu.cn (Z.W.); changs64@sina.com (J.L.); zhjianying@gmail.com (J.Z.); \\ hnhhk@sina.com (H.H.) \\ 2 State Key Laboratory of Powder Metallurgy, Central South University, Changsha 410083, China; \\ a304b8@csu.edu.cn \\ * Correspondence: xiexiaoli@csu.edu.cn; Tel.: +86-731-82355112
}

check for

updates

Citation: Wu, Z.; Luo, J.; Zhang, J.; Huang, H.; Xie, Z.; Xie, X.

Silver-Releasing Micro-/Nanoporous Coating on Additively Manufactured Macroporous Ti-Ta-Nb-Zr Scaffolds with High Osseointegration and Antibacterial Properties. Coatings 2021, 11, 716. https://doi.org/ 10.3390/coatings11060716

Academic Editor: Ajay Vikram Singh

Received: 24 May 2021

Accepted: 10 June 2021

Published: 15 June 2021

Publisher's Note: MDPI stays neutral with regard to jurisdictional claims in published maps and institutional affiliations.

Copyright: (c) 2021 by the authors. Licensee MDPI, Basel, Switzerland. This article is an open access article distributed under the terms and conditions of the Creative Commons Attribution (CC BY) license (https:/ / creativecommons.org/licenses/by/ $4.0 /)$.

\begin{abstract}
The two major problems of titanium alloy surface of bone/dental implants were the lack of native tissue integration and associated infection. To solve these problems, the development of self-defending implants with intrinsic osteogenic properties has been highlighted, in which titanium alloy surfaces of bone/dental implants are endowed with antibacterial property by silver (Ag) incorporated in biomaterials. In this study, we biofunctionalized the surface of selective laser melting (SLM) manufactured volume-porous Ti-Ta-Nb-Zr scaffolds by using plasma electrolytic oxidation (PEO) as a way to eliminate the peri-operative bacterial load and promote osseointegration. In the experiment, the PEO process operated with three different concentration (1, 1, and $2 \mathrm{~g} / \mathrm{L}$ ) of a AgNO3 solution. As a result, a titanium oxide coating embedded with calcium and phosphorous and $\mathrm{Ag}$ was formed by one-step PEO treatment, and a presence of HAp was detected by X-ray diffraction (XRD) and XPS. In addition, Ag ions were found to be released from the scaffolds for at least 28 days, resulting in an effective prevention of bacterial adhesion and a decrease of the number of planktonic bacteria, with no sign of cytotoxicity shown simultaneously. Highly porosity micropores were formed on the surface of scaffolds after oxidation, and the mechanical properties did not show any signs of change. Besides, a strong calcium deposition and osteoconductive effect were found on the surface of PEO-treated Ag scaffolds. To sum up, this study reveals the potential of PEO coatings to biofunctionalize SLM Ti-Ta-Nb-Zr scaffolds with antibacterial agents. The biomaterials developed here, therefore, exploit the biofunctionalized behavior of Ag to offer strong antibacterial behavior and osteogenic promotion without cytotoxicity of Ag against mammalian cells.
\end{abstract}

Keywords: selective laser melting; antibacterial surfaces/coatings; porous implants; plasma electrolytic oxidation; surface biofunctionalization

\section{Introduction}

Implant-associated infections (IAIs) are one of the main causes of implant failure [1]. The prevalence of IAIs is anticipated to increase with the number of patients receiving orthopedic implants grows, which accounts for both the burden on healthcare costs and the suffering of patients [2,3]. Particularly, patients are vulnerable to bacterial infections, with aging, diabetes, or osteoporosis, which exacerbate their bone healing [4]. IAIs are considered a severe fiscal and clinical burden. Therefore, the urgent development of antibacterial strategies to minimize the risk of IAIs is of utmost significance.

Initially, bacteria accumulate on the surface of the implant through invasion into the wound cavity. Although titanium and its alloys have many advanced physicochemical and biological properties, they still face the challenge of a high incidence of associated infection [5,6]. In particular, customized implants made by additive manufacture are more 
vulnerable to bacterial invasion and infection [7]. van Hengel et al. presented two major strategies to minimize the risk of IAIs [8]. First, rapid formation of new bones is promoted to reduce the risk of biofilm formation effectively. Geometrically complex and porous implants fabricated by additive manufacturing can accelerate the osseointegration process by providing an available space for bony tissue to grow into $[9,10]$. Consequently, the contact area between the implant and bony tissue is greatly increased. However, the porous structure makes it more difficult to fully eradicate planktonic bacteria. To further diminish this concern, the antibacterial ability of the porous implant surface is strengthened, which represents the second strategy.

The integration of both the aforementioned strategies is rarely reported in the existing titanium implants [11]. At present, it has been reported that hydroxyapatite and antibiotics can be deposited on the surfaces of metal implants by the sol-gel method [12,13]. However, the process of this method is relatively complex and there are many steps and processes, so it is difficult to popularize in clinical practice. Therefore, we proposed the idea of performing surface biofunctionalization via "one-step" plasma electrolytic oxidation (PEO) on additively manufactured (AM) porous implants to create multifunctional surfaces that enhance the osteogenic differentiation of the implants while exhibiting antibacterial potential. Therefore, we proposed the idea of performing surface biofunctionalization via PEO on AM porous implants to create multifunctional surfaces that enhance the osteogenic differentiation of the implants while exhibiting antibacterial potential. Due to its great potential for introducing multiple functionalities in a fast single-step procedure, PEO was chosen as a surface biofunctionalization technique, which could sustain the release of metal ions to maintain long-term antibacterial performance [14-16]. In addition, Ca and $\mathrm{P}$ contained in the electrolytes were used in the PEO process, both of which can promote osteogenic differentiation [17].

Silver (Ag) with well-recognized broad-spectrum antibacterial activity is widely applied in clinical practice [18]. With widespread usage of Ag, the limitation of its further use is toxicity to eukaryotic cells [19]. It was reported that Ag in the form of nanoparticles (NPs) on the surfaces of implants could avoid cytotoxicity both in vitro and in vivo [14,20].

PEO modification with Ag on AM porous Ti-6Al-4V (Ti64) alloys, as previous studies have proven, indeed results in high osseointegration and antibacterial activity $[8,14,21,22]$. Ti64 releases vanadium $(\mathrm{V})$ and aluminum $(\mathrm{Al})$ ions to the surrounding biological environment, which result in adverse effects $[23,24]$. Our previous work demonstrated that AM Ti-10Ta-2Nb-2Zr (as-TTNZ) possessed lower stress shielding and better osteogenic differentiation than Ti64 [25]. To our knowledge, rare reports about Ag NPs-coating Ti-Ta$\mathrm{Nb}-\mathrm{Zr}$ alloy surfaces. Therefore, we hypothesized that porous as-TTNZ-incorporated Ag NPs exhibited bactericidal behavior without any cytotoxicity, accompanied by a strong osteogenic effect.

In the current work, multifunctional coatings were formed on AM porous Ti-10Ta$2 \mathrm{Nb}-2 \mathrm{Zr}$ surfaces, and their physicochemical characteristics were studied. Moreover, we explored their performance against Staphylococcus aureus (S. aureus) and Escherichia coli (E. coli) bacteria in vitro. Finally, we investigated the response of host cells to the samples and assessed their metabolic and alkaline phosphatase (ALP) activities.

\section{Materials and Methods}

\subsection{Additive Manufacturing}

The design of a face-centered cubic (FCC) unit cell is presented. FCC unit cells were stacked to fabricate samples with a thickness of $3 \mathrm{~mm}$ and a diameter of $10 \mathrm{~mm}$. Selective laser melting (SLM) was performed on a Dimetal-100 machine (Laseradd Technology Co Ltd., Guangzhou, China) to produce porous as-TTNZ samples under an argon atmosphere with less than $80 \mathrm{ppm}$ oxygen. The SLM printer was equipped with a ytterbium fiber laser (IPG Photonics Corporation, Oxford, MA, USA) kept at room temperature between 15 and $26^{\circ} \mathrm{C}$, while the humidity remained below $40 \%$. The laser scanning speed was $700 \mathrm{~mm} / \mathrm{s}$ with a layer thickness of $25 \mu \mathrm{m}$. The laser power was set at $170 \mathrm{~W}$, and the spot size was 
$70 \mu \mathrm{m}$ in diameter. Ti-10Ta-2Nb-2Zr powder, with a particle size of $15-70 \mu \mathrm{m}$, was used with a spherical shape, which we have presented elsewhere [25]. The printed samples were treated with ultrasonic cleaning in ethyl alcohol for $15 \mathrm{~min}$.

\section{2. $P E O$}

The PEO process was performed in an aqueous electrolyte solution containing $4 \mathrm{~g} / \mathrm{L}$ $\left(\mathrm{CH}_{3} \mathrm{COO}\right)_{2} \mathrm{Ca}, 8 \mathrm{~g} / \mathrm{L} \mathrm{Na}_{2} \mathrm{SiO}_{3}, 3 \mathrm{~g} / \mathrm{L} \mathrm{NaOH}, 3 \mathrm{~g} / \mathrm{L}$ glycerin, and $2 \mathrm{~g} / \mathrm{L}$ EDTA for $4 \mathrm{~min}$. The $\mathrm{Ag}$ antibacterial agent was introduced into the electrolyte solution in the form of silver nitrate at concentrations of $1,1.5$, and $2 \mathrm{~g} / \mathrm{L}$. The working voltage was $480 \mathrm{~V}$ with a pulse frequency of $600 \mathrm{~Hz}$ and a duty ratio of $8 \%$. Next, the substrates were rinsed with distilled water for $10 \mathrm{~min}$ and dried at $60{ }^{\circ} \mathrm{C}$ overnight.

\subsection{Surface Characterization}

The morphology and microstructure of the coatings were investigated by field emission scanning electron microscopy (FEI QUANTA 200, FEI, Amsterdam, The Netherlands) coupled with EDS. The samples were analyzed by X-ray diffraction (XRD). The chemical composition of the PEO-treated surface was analyzed using XPS.

\subsection{Ag Ion Release Kinetics}

To investigate the release kinetics of Ag ions, the PEO-treated porous as-TTNZ and as-TTNZ scaffolds ( $n=4)$ were immersed in $5 \mathrm{~mL}$ of phosphate-buffered saline (PBS) in darkness at $37{ }^{\circ} \mathrm{C}$. PBS was collected and replenished after 1, 3, 7, 14, 21, and 28 days. The Ag ion release of the samples was measured by inductively coupled plasma mass spectrometry (ICP-MS, PerkinElmer, Massachusetts, MA, USA).

\subsection{Mechanical Properties}

To investigate the static mechanical behavior of the scaffolds $(n=4)$, compression tests and the elastic modulus were evaluated by a Sansi universal materials testing machine (Sansi, Shenzhen, China) at room temperature. The length and size of the scaffolds were designed based on ISO 13314:2011 (the scaffolds were cylinder-shaped with a size of $120 \mathrm{~mm}$ in length and $10 \mathrm{~mm}$ in diameter). In this test, a stress strain of $10 \%$ for the scaffolds tested was regarded as the compressive strength [26]. The rate of load application for the compression test was $2 \mathrm{~mm} / \mathrm{min}$.

\subsection{Apatite Forming Ability}

To study the bioactivity in vitro, the scaffolds were immersed in $15 \mathrm{~mL}$ of the simulated body fluid (Phygene, Fu Zhou, China) at $37^{\circ} \mathrm{C}$ for 7 and 21 days. The simulated body fluid (SBF) was refreshed every other day. According to previous research, the formation of apatite on the surface was observed by SEM and EDS [27].

\subsection{Cell Proliferation}

After the sterilization of the scaffolds, human-osteoblast-like cells (MG-63) were cultured on the untreated and PEO-treated Ag groups $(n=3)$. The MG-63 cells were cultured at an initial density of $4 \times 10^{4}$ cells per $100 \mu \mathrm{L}$ to measure proliferation. As previously mentioned, the scaffolds were cultured in alpha Dulbecco's modified Eagle's medium containing $10 \% \mathrm{FBS}, 100 \mathrm{U} \mathrm{ml}^{-1}$ penicillin and $100 \mathrm{\mu g}^{-1}$ streptomycin, all of which were from Gibco, at $37{ }^{\circ} \mathrm{C}$ in an atmosphere of $5 \% \mathrm{CO}_{2}$ and $95 \%$ air [25]. After 1, 3, 5 , and 7 days of incubation, the number of viable cells was evaluated by a Cell Counting Kit-8 (CCK-8, Biosharp, Hefei, China).

\subsection{Fluorescence Microscopy}

To investigate the cell morphology of the osteoblasts on the surfaces of the scaffolds, MG-63 cells were selected and observed by confocal laser scanning microscopy (SP8, LEICA Co., Weztlar, Germany). The cells were seeded on the surfaces of different scaffolds at a 
density of $5 \times 10^{4}$ cells/sample. After incubation for 2 and $24 \mathrm{~h}$, the scaffolds were washed twice with PBS and fixed with $4 \%$ paraformaldehyde for $1 \mathrm{~h}$, followed by permeabilization with $0.1 \%$ Triton-100. After that, the cells were stained with DAPI (Dalian Meilun Biotechnology Co., Dalian, China) for $15 \mathrm{~min}$. After staining, the scaffolds were washed twice with PBS and observed by confocal laser scanning microscopy.

\subsection{Protein Adsorption Assay}

To evaluate the protein adsorption of the scaffolds, the scaffolds were ultrasonicated in $75 \%$ ethyl alcohol for $15 \mathrm{~min}$ and measured by a BCA Assay Kit (Biosharp, Hefei, China). According to the manufacturer's instructions, the total protein concentration was determined by the optical density (OD) at $562 \mathrm{~nm}$.

\subsection{Antibacterial Assays}

\subsubsection{Bacterial Culture and Inoculation}

Gram-negative $(\mathrm{G}-)$ E. coli and Gram-positive $(\mathrm{G}+)$ S. aureus were chosen to test the antibacterial activities of the untreated and PEO-treated Ag scaffolds. After incubation for $2 \mathrm{~h}$ while shaking at $120 \mathrm{rpm}$, both strains were cultured aseptically in a Luria-Bertani (LB) nutrient broth or trypticase soy broth (TSB) medium at $37^{\circ} \mathrm{C}$. Subsequently, the optical density at $600 \mathrm{~nm}\left(\mathrm{OD}_{600}\right)$ was measured. The concentrations of E. coli and S. aureus were adjusted to $10^{6} \mathrm{CFU} / \mathrm{mL}$. All test strains were freshly prepared.

\subsubsection{Antibacterial Assessment}

The samples were cocultured with $400 \mu \mathrm{L}$ of bacterial suspension $\left(1.5 \times 10^{5}\right.$ cells in TSB) at $37^{\circ} \mathrm{C}$ for $24 \mathrm{~h}$ in a 48 -well plate. The planktonic number was assessed by serial dilution using the plate counting method. To determine the number of adherent bacteria, the samples were rinsed 3 times in PBS. Subsequently, every sample was ultrasonicated in $1 \mathrm{~mL}$ of PBS for $5 \mathrm{~min}$. Afterward, the bacterial suspension was diluted 10-fold with PBS, and $50 \mu \mathrm{L}$ of the diluted bacterial suspension were recultivated onto a standard agar culture plate for $24 \mathrm{~h}$.

\subsection{Alkaline Phosphatase (ALP) Assay}

MG-63 cells with a density of $1 \times 10^{4}$ cells/well were seeded on scaffolds $(n=3)$ in 48-well plates. After incubation in modified Eagle's medium for one day, scaffolds were placed in osteogenic media (100 $\mathrm{nM}$ dexamethasone, $10 \mathrm{mM}$ beta-glycerol phosphate, and $50 \mathrm{~g} / \mathrm{mL}$ ascorbic acid). The ALP activity of MG-63 cells on the sample was measured after incubation for 7 days. The culture was fixed with $4 \%$ paraformaldehyde and stained with an ALP kit (Beyotime, Shanghai, China). The OD absorbance values at $405 \mathrm{~nm}$ were obtained to determine the ALP activity.

\subsection{Statistical Analysis}

SPSS version 22 (IBM, Chicago, IL, USA) was used for the statistical analysis. All quantitative results are expressed as mean $\pm \mathrm{SD}$. Analysis of variance was used to compare group differences, and a $p$-value of $<0.05$ was considered statistically significant for all tests.

\section{Results}

\subsection{Surface Morphology and Chemical Characterization of the Coatings}

SEM images of the surface morphology following Ca/P-based electrolyte PEO biofunctionalization with silver (1, 1.5, and $2 \mathrm{~g} / \mathrm{L})$ NPs are depicted in Figure 1A. Partially molten and unmolten powder particles were attached to enhance the surface areas of the highly porous scaffolds. A volcano-like porous structure was successfully formed, and these pores were affected by the concentration of silver ions. The quantification of the atomic percentage of $\mathrm{Ag}$ reached a peak at a $\mathrm{Ag}$ concentration of $1.5 \mathrm{~g} / \mathrm{L}$. SEM analysis revealed the micro-/nanoporous oxide layers were covered homogeneously on the surfaces 
of scaffolds. The homogeneous distribution of Ag was reflected on EDS mapping. A wide spread of $\mathrm{Ag}$ was fully embedded into the $\mathrm{TiO}_{2}$ surface layer.
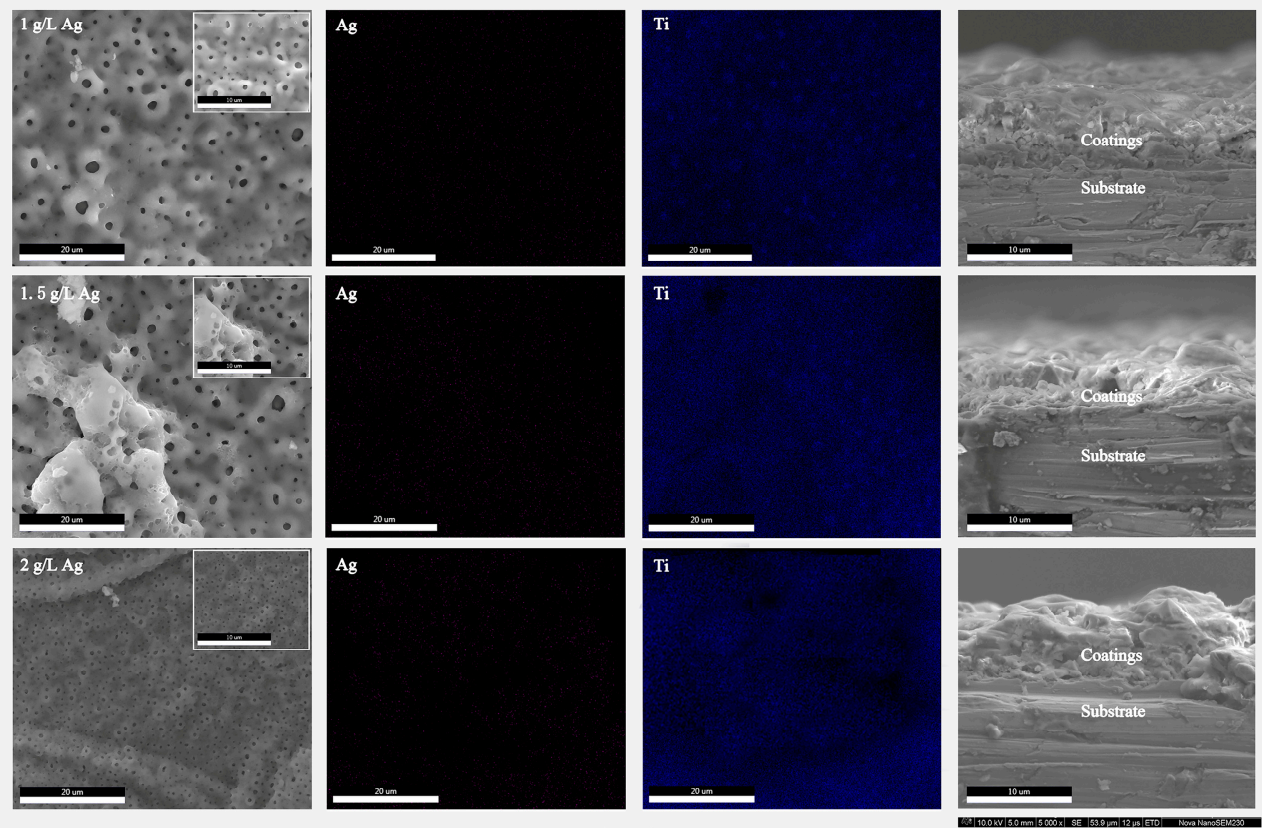

(A)

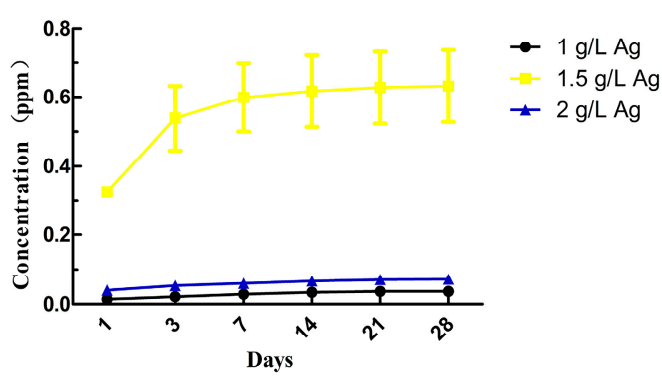

(B)

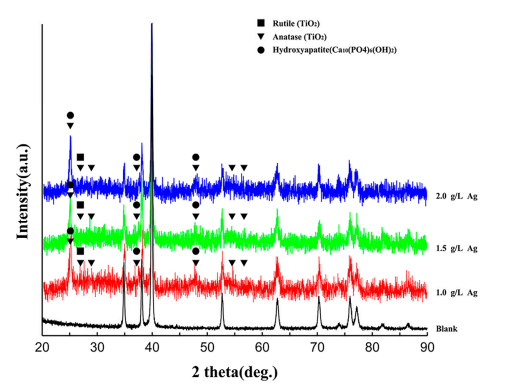

(C)

Figure 1. (A) Representative SEM images of scaffold surfaces and EDS mapping of the Ag-coated groups; (B) XRD patterns of plasma electrolytic oxidation (PEO)-treated and PEO-untreated samples; (C) cumulative release profiles of Ag ions measured during a period of 28 days.

The XRD spectra of the blank, $1 \mathrm{Ag}, 1.5 \mathrm{~g} / \mathrm{L} \mathrm{Ag}$, and $2 \mathrm{~g} / \mathrm{L} \mathrm{Ag}$ samples are presented. The existence of two titanium oxide crystalline phases (anatase and rutile) was revealed by XRD. Additionally, the existence of the HAp phase was detected. However, the peaks for planes ranging from 30.5 to 33.0 degrees in 2 theta were weak and hardly to be detected, mainly because of the low degree of crystallinity of the HAp. Ag are shown in Figure 2B. In addition, the chemical composition and state of the components in the PEO coatings were investigated by XPS, as shown in Figure 2. According to the survey spectrum, the major surface elements were Ti, O, C, N, Nb, Zr, Ta, Ca, P, and Ag (Figure 2A). Figure 2B shows the fine XPS spectra of the Ag 3d peak, with peaks at 368.4 and $374.4 \mathrm{eV}$, which indicated a successful production of Ag coating. 


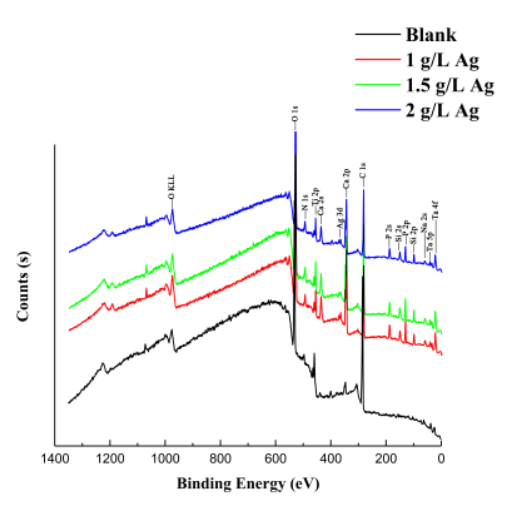

(A)

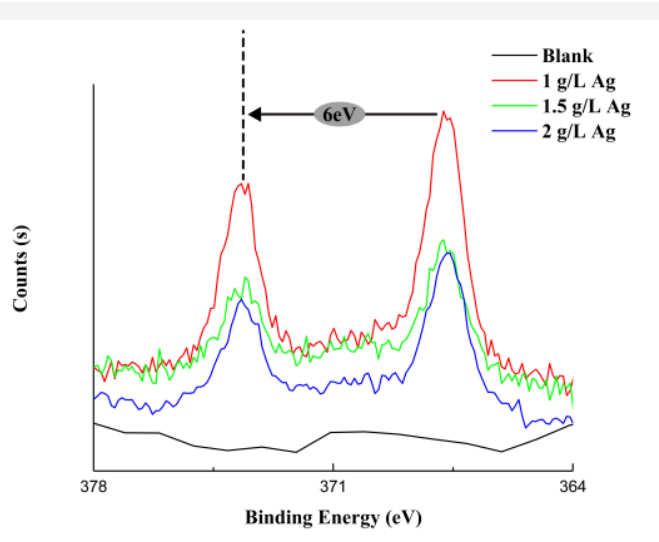

(B)

Figure 2. (A) XPS survey spectra of the PEO-treated and PEO-untreated samples; (B) high-resolution spectra of Ag 3d.

\subsection{Ag Ion Release Kinetics}

The Ag release kinetic profiles were collected for the different silver concentration groups by immersing scaffolds in $5 \mathrm{~mL}$ of PBS for 28 days. The rate of Ag release from the Ag-coated scaffolds correlated with the Ag concentrations in the electrolytes and was highest on the first day and persisted up to at least 28 days. Taking the whole duration of the release experiment into consideration, the release of $\mathrm{Ag}$ was enhanced for the $1.5 \mathrm{~g} / \mathrm{LAg}$ groups compared to those of the rest groups.

\subsection{Compression Testing}

The mechanical properties of the scaffolds (i.e., compressive strength and Young's modulus) were derived from the stress-strain relationships. The static compression tests results of the porous scaffolds are shown in Figure 3. The blank, $1 \mathrm{~g} / \mathrm{L} \mathrm{Ag}, 1.5 \mathrm{~g} / \mathrm{L} \mathrm{Ag}$, and $2 \mathrm{~g} / \mathrm{L} \mathrm{Ag}$ scaffolds exhibited compressive strength values of $100.51 \pm 15.28,109.17 \pm 15.63$, $104.91 \pm 1.40$, and $104.86 \pm 7.42 \mathrm{MPa}$, respectively (Table 1). Young's modulus was calculated from the slope of the elastic response. It can be calculated that the Young's moduli of the blank, $1 \mathrm{~g} / \mathrm{L} \mathrm{Ag}, 1.5 \mathrm{~g} / \mathrm{L} \mathrm{Ag}$, and $2 \mathrm{~g} / \mathrm{L} \mathrm{Ag}$ scaffolds were $10.89 \pm 2.25$, $13.45 \pm 4.92,11.47 \pm 0.66$, and $11.59 \pm 1.50 \mathrm{GPa}$, respectively. The compressive Young's moduli (10-14 GPa) of the PEO-treated and PEO-untreated scaffolds were in the range of the modulus of the human bone (dense bone: 2-20 GPa). The PEO treatment did not change the mechanical properties of the scaffolds, as there were no statistically significant differences in compressive strength or Young's modulus.

Table 1. Mechanical properties of the PEO-treated and -untreated scaffolds.

\begin{tabular}{ccc}
\hline Samples & Compressive Strength (MPa) & Young's Modulus (GPa) \\
\hline Blank & $100.51 \pm 15.28$ & $10.89 \pm 2.25$ \\
$1 \mathrm{~g} / \mathrm{L} \mathrm{Ag}$ & $109.17 \pm 15.63$ & $13.45 \pm 4.92$ \\
$1.5 \mathrm{~g} / \mathrm{L} \mathrm{Ag}$ & $104.91 \pm 1.40$ & $11.47 \pm 0.66$ \\
$2 \mathrm{~g} / \mathrm{L} \mathrm{Ag}$ & $104.86 \pm 7.42$ & $11.59 \pm 1.50$ \\
\hline
\end{tabular}

Note: values expressed as the mean \pm SD.

\subsection{Antibacterial Assays}

The specimens from the $1 \mathrm{~g} / \mathrm{L} \mathrm{Ag}, 1.5 \mathrm{~g} / \mathrm{L} \mathrm{Ag}$, and $2 \mathrm{~g} / \mathrm{L} \mathrm{Ag}$ groups completely prevented $S$. aureus adhesion, whereas those from the blank group showed a five-log inhibition $(p<0.001)$ compared to the specimens from the $1.5 \mathrm{~g} / \mathrm{L} \mathrm{Ag}$ and $2 \mathrm{~g} / \mathrm{L} \mathrm{Ag}$ groups (Figure 3). Similar results were obtained for adherent $E$. coli, with the blank group showing a two-log inhibition $(p<0.05)$ compared to the $1.5 \mathrm{~g} / \mathrm{L} \mathrm{Ag}$ and $2 \mathrm{~g} / \mathrm{L} \mathrm{Ag}$ groups (Figure 4). Additionally, the results obtained for planktonic bacteria with the blank group showed an obvious reduction in the number of CFUs compared to the $1.5 \mathrm{~g} / \mathrm{L} \mathrm{Ag}$ and $2 \mathrm{~g} / \mathrm{L} \mathrm{Ag}$ 
groups $(p<0.001)$. Among them, the numbers of planktonic $S$. aureus CFUs and E. coli CFUs between the $1.5 \mathrm{~g} / \mathrm{L} \mathrm{Ag}$ group and the $1 \mathrm{~g} / \mathrm{L} \mathrm{Ag}$ group were obviously lower $(p<0.001)$ and statistically lower $(p<0.05)$, respectively.

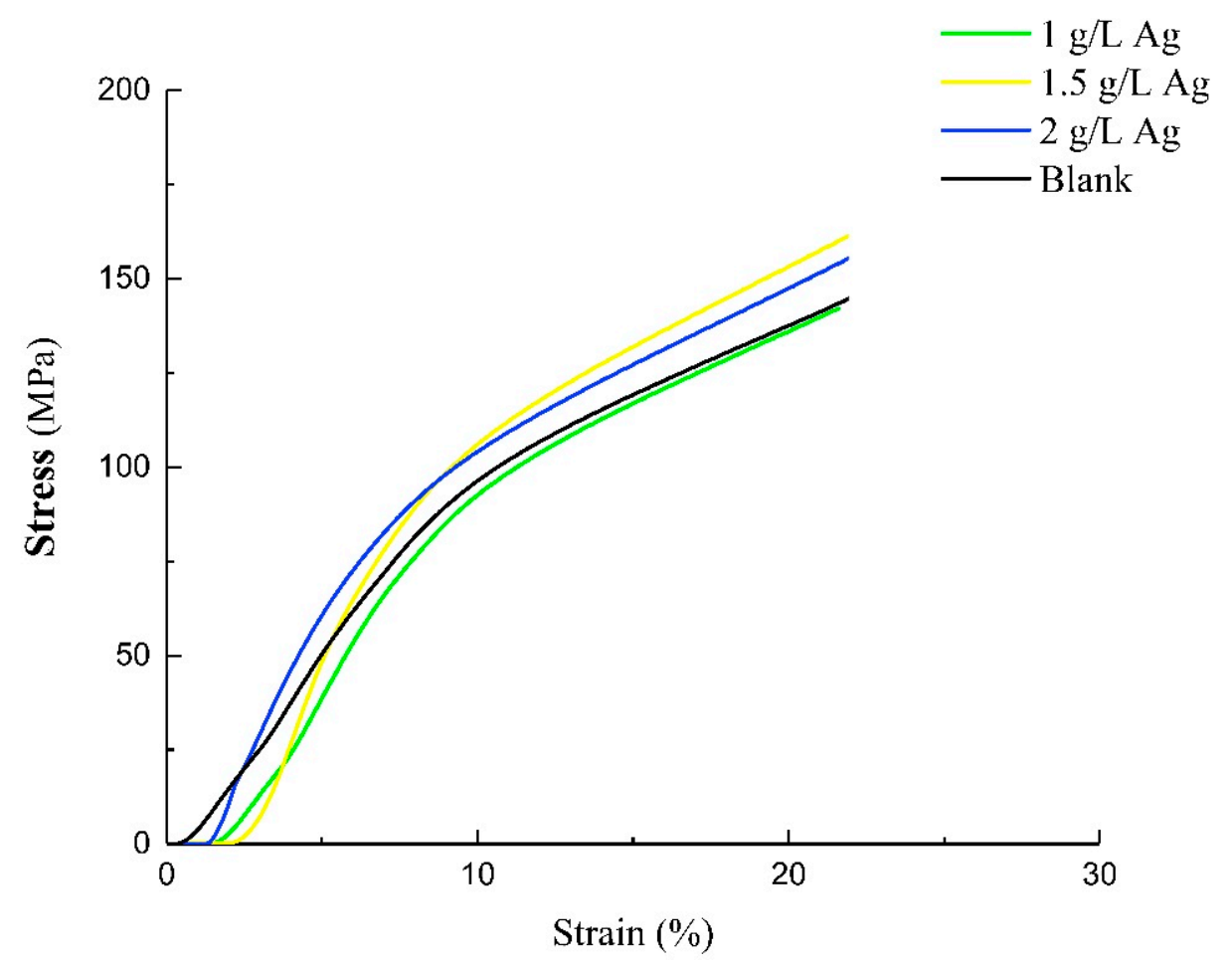

Figure 3. Stress vs. strain curves.

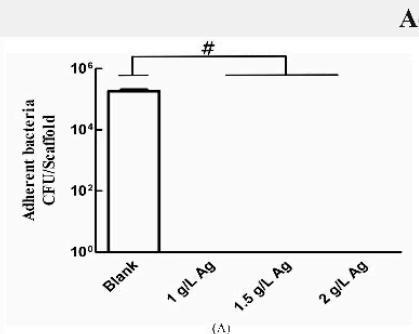

Adhesion

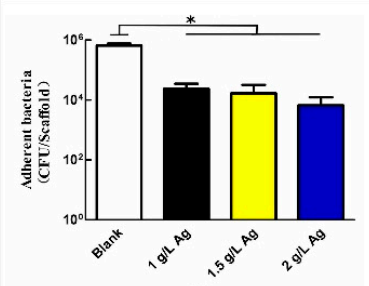

Suspension

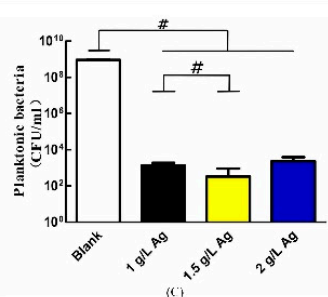

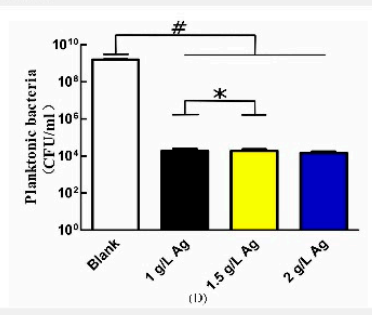

Figure 4. The adherent and planktonic bacterial activity against an inoculum of $1.5 \times 10^{5}$ cells after $24 \mathrm{~h}$. (A,C) represent the activities of Staphylococcus aureus (S. aureus); (B,D) represent the activities of Escherichia coli (E. coli). ${ }^{*} p<0.05 ; \# p<0.01$.

\subsection{In Vitro Cytotoxic Properties}

On day 1, the cells proliferation activity of the $1 \mathrm{~g} / \mathrm{L} \mathrm{Ag}$ scaffolds was obviously higher than those cultured on the PEO-untreated scaffolds and the $1.5 \mathrm{~g} / \mathrm{L} \mathrm{Ag}$ scaffolds $(p<0.05)$ (Figure 5B). At day 3 and day 5, the cells proliferation activity of the $1.5 \mathrm{~g} / \mathrm{L} \mathrm{Ag}$ scaffolds were obviously lower than those cultured on the other Ag scaffolds $(p<0.05)$. After day 7, the growth activity was enhanced for cells on the $2 \mathrm{~g} / \mathrm{L} \mathrm{Ag}$ scaffolds compared to on the blank, $1 \mathrm{~g} / \mathrm{L} \mathrm{Ag}$, and $1.5 \mathrm{~g} / \mathrm{L} \mathrm{Ag} \mathrm{scaffolds}(p<0.05)$. 

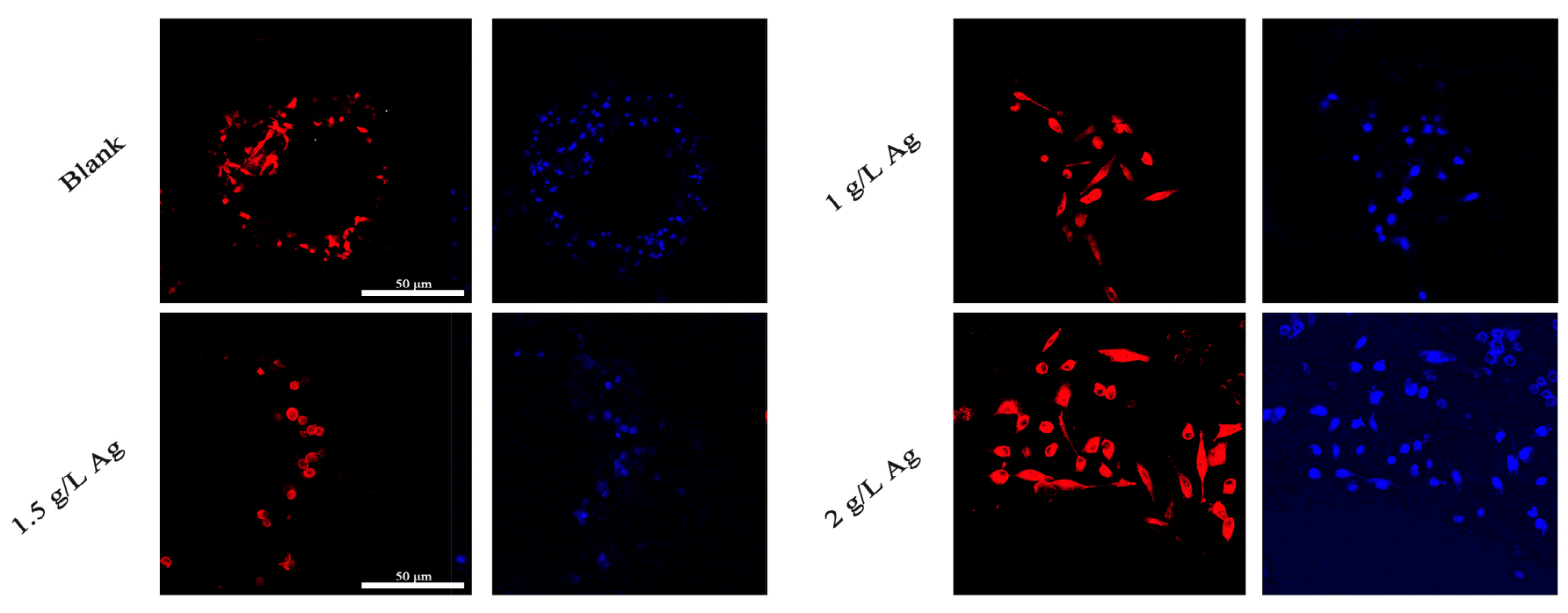

(A)

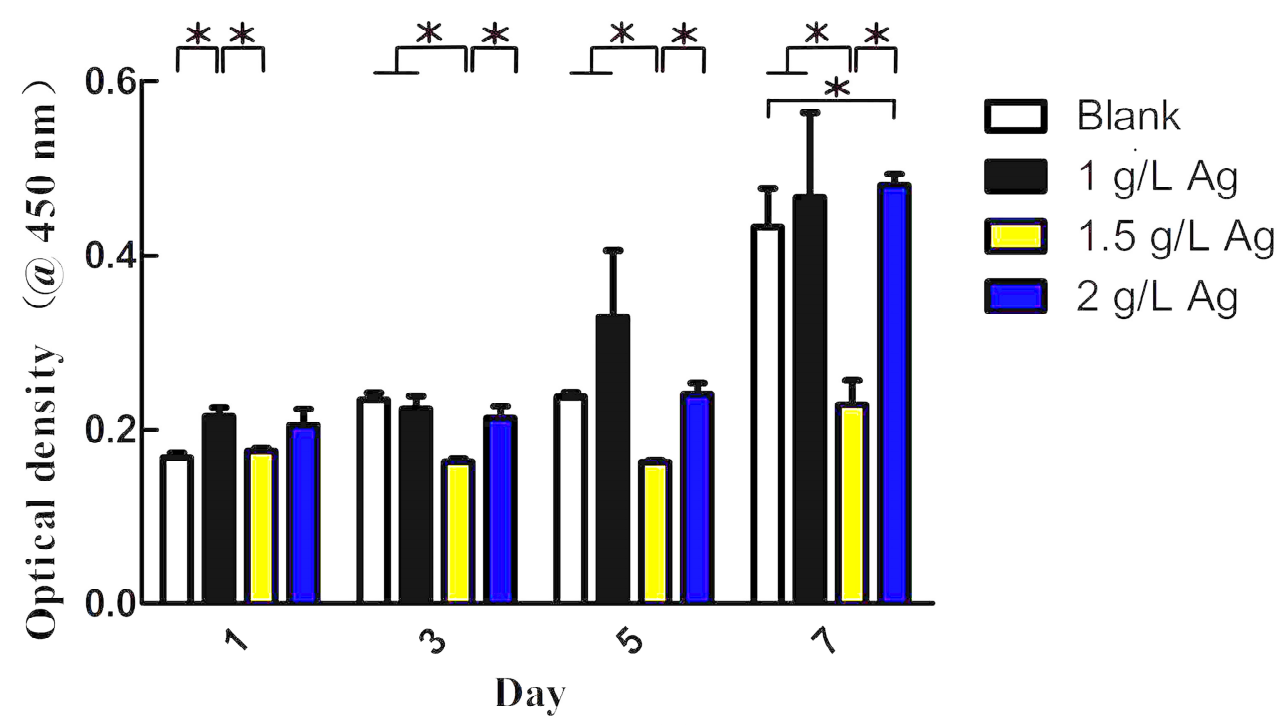

(B)

Figure 5. (A) Fluorescence images (stained with phalloidin and DAPI) of cells attached after $24 \mathrm{~h}$ of incubation; (B) CCK-8 assay showing the metabolic activity of MG-63 cells after 1, 3, 5, and 7 days of incubation ${ }^{*} p<0.05$; \# $\left.p<0.01\right)($ the red color represents the cytoskeleton, and the blue color represents the nucleus).

Additionally, the adherent cells were observed by DAPI staining after culture for $24 \mathrm{~h}$ (Figure 5A). The observed cell morphology indicated that the cells spread relatively poorly onto the surface of $1.5 \mathrm{~g} / \mathrm{L} \mathrm{Ag}$ while the cells dramatically promoted cell extension onto the surface of $2 \mathrm{~g} / \mathrm{L} \mathrm{Ag}$.

\subsection{Apatite-Forming Ability}

The SEM images of the apatite layer after soaking in SBF for 7 and 21 days are depicted in Figure 6. The apatite layer was deposited over the surface of the PEO-treated scaffolds. The image showed that the apatite layer was abundant in the $2 \mathrm{~g} / \mathrm{L} \mathrm{AgNO}_{3}$ group. In contrast, the apatite layer was not found on the untreated scaffold after immersion for 21 days. The EDS mapping analysis reflected that the $\mathrm{Ca} / \mathrm{P}$ ratio of the $2 \mathrm{~g} / \mathrm{L} \mathrm{AgNO} 3$ group was closer to the desired $\mathrm{Ca} / \mathrm{P}$ molar ratio, which agrees with the chemical composition of human bone tissue. 


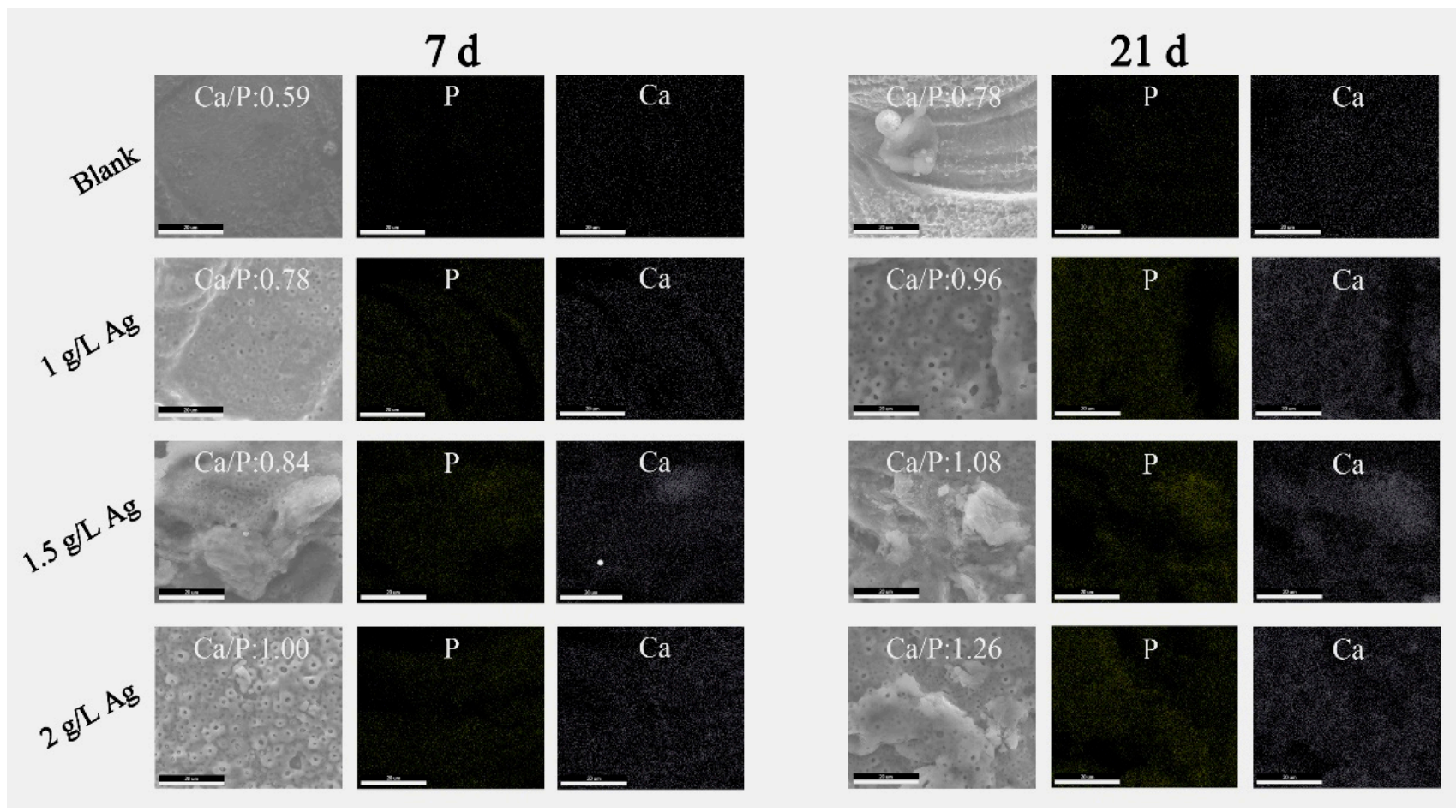

Figure 6. SEM images of the PEO-treated and untreated scaffolds immersed in SBF for 7 and 21 days.

\subsection{Osteogenic Differentiation and Protein Adsorption}

The protein adsorption capabilities of the blank, $1 \mathrm{~g} / \mathrm{L} \mathrm{Ag}, 1.5 \mathrm{~g} / \mathrm{L} \mathrm{Ag}$, and $2 \mathrm{~g} / \mathrm{L} \mathrm{Ag}$ groups were observed by using the model protein BSA. According to the data summary shown in Figure 7A, the protein adsorption level of the $2 \mathrm{~g} / \mathrm{L} \mathrm{Ag}$ group was significantly higher than that of the blank and $1.5 \mathrm{~g} / \mathrm{L}$ Ag groups $(p<0.05)$.

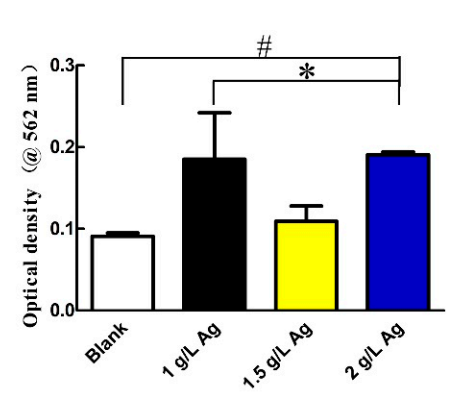

(A)

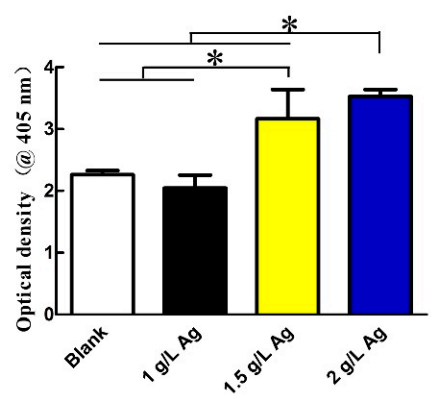

(B)

Figure 7. (A) Protein adsorptions on the PEO-treated and untreated scaffolds ( ${ }^{*} p<0.05 ; \# p<0.01$ ); (B) alkaline phosphatase (ALP) activity of MG-63 cells cultivated on the scaffolds at 7 days $\left({ }^{*} p<0.05\right.$; $\# p<0.01)$.

In addition, we compared the osteogenic differentiation evaluated by using humanosteoblast-like cells on the four groups of scaffolds using ALP as an early phase marker. The $2 \mathrm{~g} / \mathrm{L} \mathrm{Ag}$ group exhibited a significantly higher ALP activity than the blank and $1 \mathrm{~g} / \mathrm{L}$ Ag groups $(p<0.05)$ after 7 days of culture. The findings indicated that the $2 \mathrm{~g} / \mathrm{L} \mathrm{Ag}$ scaffolds showed superior osteogenic differentiation.

\section{Discussion}

The major causes of the failure of dental and orthopedic implants was lack of native tissue integration and the occurrence of infection [11]. AM porous Ti-10Ta-2Nb-2Zr bio- 
materials covered with volcano-like surfaces containing silver-based antimicrobial agents were developed in this research study. Herein, the suitability of PEO for surface biofunctionalization of AM Ti-10Ta-2Nb-2Zr scaffolds was confirmed, and the optimization of their electrolyte and technology parameters in terms of in vitro cytocompatibility, antibacterial efficiency, and osteogenesis performance were also determined.

After the PEO process, a volcano-like porous structure was detected on the surface scaffolds. During the process, these pores were formed and contained an antibacterial agent coatings through combining electrochemical oxidation with a high voltage spark treatment in an aqueous electrolytic bath with a silver element in the form of dissolved salts [28]. PEO, as a surface modification technology, can endow materials with biological properties by compound biofunctional oxide layers with interconnected micro/nanoporosity. Previous studies have shown that PEO may affect the mechanical properties of materials [29,30]. However, our study shows that there is no significant effect on the compressive strength and elastic modulus of PEO-treated AM titanium scaffolds. The results of this study are consistent with Karaji et al. [31].

Silver was identified on the surface of $1 \mathrm{~g} / \mathrm{L} \mathrm{Ag}, 1.5 \mathrm{~g} / \mathrm{L} \mathrm{Ag}$, and $2 \mathrm{~g} / \mathrm{L} \mathrm{Ag}$ scaffolds. Moreover, the presence of HAp crystals was detected by XRD. The osseointegration ability of coatings was enhanced by the presence of HAp $[17,32]$. Similar work examining thermal treatment and higher temperatures may lead to the formation of hydroxyapatite phases [33].

The chemical composition and state of the components on the surface of scaffolds by XPS were shown in Figure 2. Doublet signals were detected in the Ag 3d, Ti 2p, and Ca 2p core-level spectra. Together with the P $2 p$ spectrum, the PEO-treated scaffolds may provide a favorable chemical environment for the formation of calcium phosphate compounds [34]. The gap between the $\mathrm{Ag} 3 \mathrm{~d}$ doublets was $6 \mathrm{eV}$, which revealed metallic silver $(\mathrm{Ag}(0))$ [35].

No matter whether Ag NPs are taken in by cells via diffusion, endocytosis, or phagocytosis, Ag NPs themselves or $\mathrm{Ag}^{+}$ions can induce ROS generation and interrupt ATP synthesis, thereby leading to DNA damage and even affecting cell proliferation [36,37]. A high concentration of silver may be cytotoxic, but it exhibits cytocompatibility at low concentrations [38]. Embedding Ag NPs into an oxide layer not only confers gradual Ag ion release, but also effectively reduces cytotoxicity [14]. The $1 \mathrm{~g} / \mathrm{L} \mathrm{Ag}$ and $2 \mathrm{~g} / \mathrm{L} \mathrm{Ag}$ groups exhibited good cytocompatibility. Even the abilities of the $1 \mathrm{~g} / \mathrm{L} \mathrm{Ag}$ and $2 \mathrm{~g} / \mathrm{L} \mathrm{Ag}$ groups to promote cell proliferation were significantly better than those of the blank group on day 1 and day 7 , respectively. The reason for this phenomenon may be related to the release of silver ions. As shown in Figure 1B, the silver ion release of each group reached a peak at $24 \mathrm{~h}$, but the silver ion release of the $1.5 \mathrm{~g} / \mathrm{L} \mathrm{Ag}$ group was much higher than those of the other two groups. Similarly, human-osteoblast-like cells revealed good attachment and adequate spreading and proliferation on the $2 \mathrm{~g} / \mathrm{L} \mathrm{Ag}$ scaffold surfaces. Attributing to HAp incorporated into the nanotubular matrix, the enhanced cell spread on the $2 \mathrm{~g} / \mathrm{L} \mathrm{Ag}$ scaffolds [39]. In addition, the complicated surface topography with nanoscale features is conducive to a higher effective contact area, which is beneficial for enhancing a more homogeneous distribution of absorbed protein [40]. This was also confirmed in the protein adsorption experiment (Figure 5B), which is consistent with the results of previous studies.

An EDS investigation was also used to test the $\mathrm{Ca} / \mathrm{P}$ molar ratio in apatite forming ability. The EDS investigation indicated the formation of apatite on the $2 \mathrm{~g} / \mathrm{L} \mathrm{Ag}$ scaffolds where the $\mathrm{Ca} / \mathrm{P}$ ratio was approximately 1.26 , closer to 1.67 , which referred to the mineral phase of HAp. Despite the presence of the antibacterial Ag inclusions, the SEM morphologies indicated that the apatite layer was deposited over the surface of the PEO-treated scaffolds within 7 days. These findings are in line with previous research, showing that an incorporated antibacterial agent does not hinder osseointegration between the substrate coating contained in the HAp and bone tissue [21]. Kokubo et al. suggested that there is a positive relationship between the capability of a material to form apatite on its surface and the in vivo bone bioactivity of the material [41]. Furthermore, after 7 days of culture, the scaffolds of the $1.5 \mathrm{~g} / \mathrm{L} \mathrm{Ag}$ and $2 \mathrm{~g} / \mathrm{L} \mathrm{Ag}$ groups showed significant differences in ALP expression compared with those of the $1 \mathrm{~g} / \mathrm{L} \mathrm{Ag}$ and blank groups, 
respectively. All of these results revealed that our biofunctionalized surface induced no cytotoxic effects against preosteoblast cells. In fact, the hydroxyapatite was formed onto the $\mathrm{TiO}_{2}$ substrate surface layer amid the PEO biofunctionalization process [21]. Taken together, the micro/nanoporous structure of the coating could promote the osteogenic properties of the substrate $[17,42]$.

With the widespread and increasing demand for porous implants obtained by additive manufacturing, research on their antibacterial surface properties has become increasingly urgent. There are three categories of implant-associated infection, i.e., perioperative, hematogenous, and contiguous [43]. S. aureus and E. coli are two typical bacteria used to evaluate the antibacterial ability of materials [44]. In particular, S. aureus is the main pathogenic bacterium associated with implant infections [45]. In the current study, after the exposure of $S$. aureus and E. coli bacteria to as-Ti-10Ta-2Nb-2Zr scaffolds, both adherent and planktonic bacteria were evaluated. According to the colony count results (Figure 3), both planktonic and adherent S. aureus and E. coli incubated with PEO-treated Ag groups were significantly reduced compared with the PEO-untreated group. In particular, after culture with antibacterial Ag NPs scaffolds containing adherent S. aureus, almost all bacteria were eradicated as a result of the initial high $\mathrm{Ag}^{+}$concentration. Silver is cheap and readily available, and it has a strong bactericidal effect, even against antibiotic-resistant "superbugs". In contrast to other antibiotics and antimicrobial peptides, silver is highly stable and can be processed and handled in easy and economical ways, which is conducive to its large-scale industrialization [46]. In addition, doping or embedding into a coating with an adjustable microstructure can maintain its antibacterial properties [47]. The formation of bacterial biofilms often occurs at a very early time point [48]. Anti-infective treatment becomes extremely difficult, once biofilms are formed [49]. Therefore, to prevent postoperative infection, restraining the formation of bacterial biofilms within $24 \mathrm{~h}$ after implantation is the most effective method. In the current research, compared to in the blank group, reductions in the total bacterial number were detected in all PEO-treated Ag scaffolds by at least $\sim 2 \log _{10} \mathrm{CFU} / \mathrm{mL}$. It can be concluded that contact with a surface free of Ag does not show an antibacterial effect, resulting in a decrease in bacteria contact with a coating embedded with silver NPs. The data obtained demonstrated that the antibactericidal effect can also be achieved with a low silver ion content, which is consistent with other studies $[11,21,46]$.

\section{Conclusions}

This is the first attempt to develop a new antibacterial bioactive coating with high osseointegration modified by $\mathrm{PEO}$ on the surface of a 3D printed porous $\mathrm{Ti}-10 \mathrm{Ta}-2 \mathrm{Nb}-2 \mathrm{Zr}$ scaffold. Its significance lies not only in its technical novelty, but also in the ingenious combination of PEO technology and 3D printing of a nontoxic element alloy yielding good results. The material and morphological properties, release profiles, mechanical properties, antibacterial behavior, and biocompatibility of the developed biomaterials were evaluated using various material characterization techniques, antibacterial assays, and cytotoxicity tests. A sustained release of Ag was up to 28 days, and Ag NPs were embedded in the grown oxide layer together with a micro/nanoporous structure on the surface of the scaffolds. In vitro, consistently strong antibacterial behaviors against both planktonic and adherent bacteria were also observed. Moreover, the formation of a hydroxyapatite phase in the oxide layer of AM porous scaffolds was comfirmed by XRD and XPS analysis. Notably, through a single-step PEO process, significant improvements in osseointegration performance were obtained. Through this study, we confirmed that a biofunctionalized oxidation coating can be constructed on the surface of biomimetic hierarchical Ti-Ta-Nb-Zr scaffolds by a one-step PEO process. Future studies can also be performed to incorporate other metallic ions (e.g., strontium and copper) into an oxide coating and probe their effects on osteogenesis and immunogenic behavior within scaffolds under different physiological conditions. Overall, these findings could provide useful guidance for implant developers 
regarding the widespread and safe use of 3D-printed Ag-coated Ti-10Ta-2Nb-2Zr implants in the future.

Author Contributions: Conceptualization, X.X.; methodology, Z.W.; software, H.H.; validation, X.X.; investigation, J.L.; data curation, Z.W.; writing—original draft preparation, Z.W.; writingreview and editing, Z.W.; visualization, Z.X.; supervision, J.Z.; project administration, X.X.; funding acquisition, X.X. All authors have read and agreed to the published version of the manuscript.

Funding: The research for this paper was financially supported by the Science and Technology Bureau of Changsha (grant No. kq1804007), Scientific Research Foundation of Hunan Provincial Education Department (grant No. 2019JJ40209 and 2020JJ54044), and Health and Family Planning Commission of Hunan Province (grant No. 20180356). Informed Consent Statement was not applicable.

Informed Consent Statement: Not applicable.

Acknowledgments: We thank Jiani Peng (Hunan Electric Power Design Institute) for her helpful assistance during the modification of the manuscript.

Conflicts of Interest: The authors declare no conflict of interest.

\section{References}

1. Zhou, W.; Peng, X.; Ma, Y.; Hu, Y.; Wu, Y.; Lan, F.; Weir, M.D.; Li, M.; Ren, B.; Oates, T.W.; et al. Two-staged time-dependent materials for the prevention of implant-related infections. Acta Biomater. 2020, 101, 128-140. [CrossRef]

2. Seftel, A. Treatment of Infections Associated With Surgical Implants. J. Urol. 2004, 172, 2102. [CrossRef]

3. Kurtz, S.M.; Lau, E.; Watson, H.; Schmier, J.K.; Parvizi, J. Economic Burden of Periprosthetic Joint Infection in the United States. J. Arthroplast. 2012, 27, 61-65. [CrossRef]

4. Stewart, P.S.; Costerton, J.W. Antibiotic resistance of bacteria in biofilms. Lancet 2001, 358, 135-138. [CrossRef]

5. Low, K.L.; Tan, S.H.; Zein, S.H.S.; Roether, J.A.; Mouriño, V.; Boccaccini, A.R. Calcium phosphate-based composites as injectable bone substitute materials: A review. J. Biomed. Mater. Res. Part B Appl. Biomater. 2010, 94, 273-286. [CrossRef]

6. Niinomi, M. Mechanical biocompatibilities of titanium alloys for biomedical applications. J. Mech. Behav. Biomed. Mater. 2008, 1, 30-42. [CrossRef]

7. Victor, M.V.; Luke, N.C.; Gao, N.; Owen, A.; Mark, A.W.; Duncan, E.T.; James, W.A.; Morgan, L.; Steven, A.; Sarah, J.; et al. A design approach to facilitate selective attachment of bacteria and mammalian cells to additively manufactured implants. Addit. Manuf. 2020, 36, 101528.

8. Catauro, M.; Barrino, F.; Poggetto, G.; Mauro, M.; Ignazio, B.; Stefano, V. Structure, drug absorption, bioactive and antibacterial properties of sol-gel $\mathrm{SiO}_{2} / \mathrm{ZrO}_{2}$ materials. Ceram. Int. 2020, 46, 29459-29465. [CrossRef]

9. Catauro, M.; Barrino, F.; Blanco, I.; Piccolella, S.; Pacifico, S. Use of the Sol-Gel Method for the Preparation of Coatings of Titanium Substrates with Hydroxyapatite for Biomedical Application. Coatings 2020, 10, 203. [CrossRef]

10. van Hengel, I.; Putra, N.E.; Tierolf, M.; Minneboo, M.; Fluit, A.C.; Fratila-Apachitei, L.E.; Apachite, I.; Zapoor, A.A. Biofunctionalization of selective laser melted porous titanium using silver and zinc nanoparticles to prevent infections by antibiotic-resistant bacteria. Acta Biomater. 2020, 107, 325-337. [CrossRef] [PubMed]

11. Amit, B.; Indranath, M.; Anish, S.; Nairanjana, D.; Bose, S. Direct comparison of additively manufactured porous titanium and tantalum implants towards in vivo osseointegration. Addit. Manuf. 2019, 28, 259-266.

12. Shah, F.A.; Snis, A.; Matic, A.; Thomsen, P.; Palmquist, A. 3D printed Ti6Al4V implant surface promotes bone maturation and retains a higher density of less aged osteocytes at the bone-implant interface. Acta Biomater. 2016, 30, 357-367. [CrossRef]

13. Cheng, H.; Xiong, W.; Fang, Z.; Guan, H.; Wu, W.; Li, Y.; Zhang, Y.; Alvarez, M.M.; Gao, B.; Huo, K.; et al. Strontium (Sr) and silver (Ag) loaded nanotubular structures with combined osteoinductive and antimicrobial activities. Acta Biomater. 2016, 31, 388-400. [CrossRef]

14. van Hengel, I.A.J.; Riool, M.; Fratila-Apachitei, L.E.; Witte-Bouma, J.; Farrell, E.; Zadpoor, A.A.; Sebastian, A.; Apachitei, I. Selective laser melting porous metallic implants with immobilized silver nanoparticles kill and prevent biofilm formation by methicillin-resistant Staphylococcus aureus. Biomaterials 2017, 140, 1-15. [CrossRef]

15. Shivaram, A.; Bose, S.; Bandyopadhyay, A. Understanding long-term silver release from surface modified porous titanium implants. Acta Biomater. 2017, 58, 550-560. [CrossRef]

16. Uhm, S.H.; Kwon, J.S.; Song, D.H.; Lee, E.J.; Jeong, W.S.; Oh, S.; Kwang-Mahn, K.; Ha, E. Long-Term Antibacterial Performance and Bioactivity of Plasma-Engineered Ag-NPs/TiO(2). J. Biomed. Nanotechnol. 2016, 12, 1890-1906. [CrossRef]

17. Chung, C.-J.; Su, R.-T.; Chu, H.-J.; Chen, H.-T.; Tsou, H.-K.; He, J.-L. Plasma electrolytic oxidation of titanium and improvement in osseointegration. J. Biomed. Mater. Res. Part B Appl. Biomater. 2013, 101, 1023-1030. [CrossRef]

18. Russell, A.D.; Hugo, W.B. 7 Antimicrobial Activity and Action of Silver. Prog. Med. Chem. 1994, 31, 351-370. [PubMed]

19. Mijnendonckx, K.; Leys, N.; Mahillon, J.; Silver, S.; Van Houdt, R. Antimicrobial silver: Uses, toxicity and potential for resistance. BioMetals 2013, 26, 609-621. [CrossRef] 
20. Qin, H.; Cao, H.; Zhao, Y.; Zhu, C.; Cheng, T.; Wang, Q.; Peng, X.; Cheng, M.; Wang, J.; Jin, G.; et al. In vitro and in vivo anti-biofilm effects of silver nanoparticles immobilized on titanium. Biomaterials 2014, 35, 9114-9125. [CrossRef] [PubMed]

21. Sobolev, A.; Valkov, A.; Kossenko, A.; Wolicki, I.; Zinigrad, M.; Borodianskiy, K. Bioactive Coating on Ti Alloy with High Osseointegration and Antibacterial Ag Nanoparticles. ACS Appl. Mater. Interfaces 2019, 11, 39534-39544. [CrossRef] [PubMed]

22. van Hengel, I.A.J.; Tierolf, M.W.A.M.; Valerio, V.P.M.; Minneboo, M.; Fluit, A.C.; Fratila-Apachitei, L.E.; Zadpoor, A.A. Selfdefending additively manufactured bone implants bearing silver and copper nanoparticles. J. Mater. Chem. B 2020, 8, $1589-1602$. [CrossRef] [PubMed]

23. Ghulam, K.; Ayisha, S.; Zafrin, A.; Zahra, N.; Maham, G.; Mahnoor, M.; Mukhtar, S.; Batool, M.; Saleem, N.; Rasheed, T.; et al. Short term exposure to titanium, aluminum and vanadium (Ti $6 \mathrm{Al} 4 \mathrm{~V}$ ) alloy powder drastically affects behavior and antioxidant metabolites in vital organs of male albino mice. Toxicol. Rep. 2018, 5, 765-770.

24. Gomes, C.C.; Moreira, L.M.; Santos, V.J.; Ramos, A.S.; Lyon, J.P.; Soares, C.P.; Santos, F.V. Assessment of the genetic risks of a metallic alloy used in medical implants. Genet. Mol. Biol. 2011, 34, 116-121. [CrossRef]

25. Zhenhuan, W.; Yu, D.; Junsi, L.; Xiaowei, J.; Zongyu, X.; Li, L.; Xiaoli, X. Physiochemical and biological evaluation of SLMmanufactured Ti-10Ta-2Nb-2Zr alloy for biomedical implant applications. Biomed. Mater. 2020, 15, 045017. [CrossRef] [PubMed]

26. Yu, G.; Li, Z.; Hua, Y.; Liu, H.; Zhao, X.; Li, W.; Wang, X. The Effects of Post Heat Treatment on the Microstructural and Mechanical Properties of an Additive-Manufactured Porous Titanium Alloy. Materials 2020, 13, 593. [CrossRef] [PubMed]

27. Xiu, P.; Jia, Z.; Lv, J.; Yin, C.; Cheng, Y.; Zhang, K.; Song, C.; Leng, H.; Zheng, Y.; Cai, H.; et al. Tailored surface treatment of 3D printed porous Ti6Al4V by micro-arc oxidation for enhanced osseointegration via optimized bone in-growth patterns and interlocked bone/implant interface. ACS Appl. Mater. Inter. 2016, 8, 17964-17975. [CrossRef]

28. Zhao, G.; Li, X.; Xia, L.; Wen, G.; Song, L.; Wang, X.; Wu, K. Structure and apatite induction of a microarc-oxidized coating on a biomedical titanium alloy. Appl. Surf. Sci. 2010, 257, 1762-1768. [CrossRef]

29. Leoni, A.; Apachitei, I.; Riemslag, A.; Fratila-Apachitei, L.; Duszczyk, J. In vitro fatigue behavior of surface oxidized Ti35Zr10Nb biomedical alloy. Mater. Sci. Eng. C 2011, 31, 1779-1783. [CrossRef]

30. Amin Yavari, S.; Ahmadi, S.M.; van der Stok, J.; Wauthle, R.; Riemslag, A.C.; Janssen, M.; Schrooten, J.; Weinans, H.; Zadpoor, A.A. Effects of bio-functionalizing surface treatments on the mechanical behavior of open porous titanium biomaterials. J. Mech. Behav. Biomed. 2014, 36, 109-119. [CrossRef]

31. Gorgin Karaji, Z.; Hedayati, R.; Pouran, B.; Apachitei, I.; Zadpoor, A.A. Effects of plasma electrolytic oxidation process on the mechanical properties of additively manufactured porous biomaterials. Mater. Sci. Eng. C Mater. Biol. Appl. 2017, 76, 406-416. [CrossRef] [PubMed]

32. Faria, D.; Abreu, C.S.; Buciumeanu, M.; Dourado, N.; Carvalho, O.; Silva, F.S.; Miranda, G. Ti6Al4V laser surface preparation and functionalization using hydroxyapatite for biomedical applications. J. Biomed. Mater. Res. Part B Appl. Biomater. 2017, 106, 1534-1545. [CrossRef] [PubMed]

33. Durdu, S.; Deniz, Ö.F.; Kutbay, I.; Usta, M. Characterization and formation of hydroxyapatite on Ti6Al4V coated by plasma electrolytic oxidation. J. Alloy Compd. 2013, 551, 422-429. [CrossRef]

34. Song, W.-H.; Jun, Y.-K.; Han, Y.; Hong, S.-H. Biomimetic apatite coatings on micro-arc oxidized titania. Biomaterials 2004, 25, 3341-3349. [CrossRef]

35. Jia, Z.; Xiu, P.; Li, M.; Xu, X.; Shi, Y.; Cheng, Y.; Wei, S.; Zheng, Y.; Xi, T.; Cai, H.; et al. Bioinspired anchoring AgNPs onto micro-nanoporous $\mathrm{TiO}_{2}$ orthopedic coatings: Trap-killing of bacteria, surface-regulated osteoblast functions and host responses. Biomaterials 2016, 75, 203-222. [CrossRef]

36. Hsiao, I.-L.; Hsieh, Y.-K.; Wang, C.-F.; Chen, I.-C.; Huang, Y.-J. Trojan-Horse Mechanism in the Cellular Uptake of Silver Nanoparticles Verified by Direct Intra- and Extracellular Silver Speciation Analysis. Environ. Sci. Technol. 2015, 49, 3813-3821. [CrossRef]

37. Grzelak, A.; Wojewódzka, M.; Meczynska-Wielgosz, S.; Zuberek, M.; Wojciechowska, D.; Kruszewski, M. Crucial role of chelatable iron in silver nanoparticles induced DNA damage and cytotoxicity. Redox Biol. 2018, 15, 435-440. [CrossRef]

38. Cheng, H.; Li, Y.; Huo, K.; Gao, B.; Xiong, W. Long-lasting in vivo and in vitro antibacterial ability of nanostructured titania coating incorporated with silver nanoparticles. J. Biomed. Mater. Res. A 2014, 102, 3488-3499. [CrossRef]

39. Dos Santos, E.A.; Farina, M.; Soares, G.A.; Anselme, K. Chemical and topographical influence of hydroxyapatite and $\beta$-tricalcium phosphate surfaces on human osteoblastic cell behavior. J. Biomed. Mater. Res. Part A 2009, 89, 510-520. [CrossRef]

40. Lin, K.; Xia, L.; Gan, J.; Zhang, Z.; Chen, H.; Jiang, X.; Chang, J. Tailoring the Nanostructured Surfaces of Hydroxyapatite Bioceramics to Promote Protein Adsorption, Osteoblast Growth, and Osteogenic Differentiation. ACS Appl. Mater. Interfaces 2013, 5, 8008-8017. [CrossRef] [PubMed]

41. Kokubo, T.; Takadama, H. How useful is SBF in predicting in vivo bone bioactivity? Biomaterials 2006, 27, 2907-2915. [CrossRef]

42. Whiteside, P.; Matykina, E.; Gough, J.E.; Skeldon, P.; Thompson, G.E. In vitro evaluation of cell proliferation and collagen synthesis on titanium following plasma electrolytic oxidation. J. Biomed. Mater. Res. Part A 2010, 94, 38-46. [CrossRef] [PubMed]

43. Trampuz, A.; Widmer, A.F. Infections associated with orthopedic implants. Curr. Opin. Infect. Dis. 2006, 19, 349-356. [CrossRef] [PubMed]

44. Wang, Q.; Ren, L.; Li, X.; Zhang, S.; Sercombe, T.B.; Yang, K. Antimicrobial Cu-bearing stainless steel scaffolds. Mater. Sci. Eng. C 2016, 68, 519-522. [CrossRef] [PubMed] 
45. Barth, E.; Myrvik, Q.M.; Wagner, W.; Gristina, A.G. In vitro and in vivo comparative colonization of Staphylococcus aureus and Staphylococcus epidermidis on orthopaedic implant materials. Biomaterials 1989, 10, 325-328. [CrossRef]

46. Jia, Z.; Xiu, P.; Xiong, P.; Zhou, W.; Cheng, Y.; Wei, S.; Zheng, Y.; Xi, T.; Cai, H.; Liu, Z.; et al. Additively Manufactured Macroporous Titanium with Silver-Releasing Micro-/Nanoporous Surface for Multipurpose Infection Control and Bone Repair-A Proof of Concept. ACS Appl. Mater. Interfaces 2016, 8, 28495-28510. [CrossRef] [PubMed]

47. Zhao, L.; Wang, H.; Huo, K.; Cui, L.; Zhang, W.; Ni, H.; Zhang, Y.; Wu, Z.; Chu, P.K. Antibacterial nano-structured titania coating incorporated with silver nanoparticles. Biomaterials 2011, 32, 5706-5716. [CrossRef] [PubMed]

48. Darouiche, R.O. Treatment of Infections Associated with Surgical Implants. N. Engl. J. Med. 2004, 350, 1422-1429. [CrossRef]

49. Yavari, S.A.; Loozen, L.; Paganelli, F.L.; Bakhshandeh, S.; Lietaert, K.; Groot, J.A.; Fluit, A.C.; Boel, C.H.E.; Alblas, J.; Vogely, H.C.; et al. Antibacterial Behavior of Additively Manufactured Porous Titanium with Nanotubular Surfaces Releasing Silver Ions. ACS Appl. Mater. Interfaces 2016, 8, 17080-17089. [CrossRef] 